
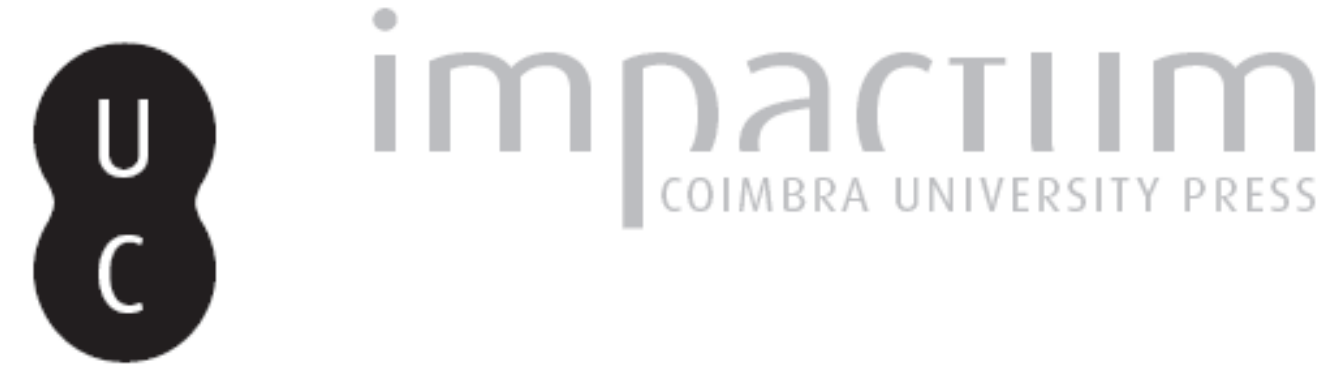

The Atlantic Arc: new translations for an old identity

Autor(es): $\quad$ Espineira, Tamara Guirao

Publicado por: Centro de Informação Europe Direct de Aveiro; Centro de Estudos

Interdisciplinares do Século XX

URL

persistente:

URI:http://hdl.handle.net/10316.2/33987

DOI:

DOI:http://dx.doi.org/10.14195/1647-6336_11_16

Accessed : $\quad$ 26-Apr-2023 11:23:08

A navegação consulta e descarregamento dos títulos inseridos nas Bibliotecas Digitais UC Digitalis, UC Pombalina e UC Impactum, pressupõem a aceitação plena e sem reservas dos Termos e Condições de Uso destas Bibliotecas Digitais, disponíveis em https://digitalis.uc.pt/pt-pt/termos.

Conforme exposto nos referidos Termos e Condições de Uso, o descarregamento de títulos de acesso restrito requer uma licença válida de autorização devendo o utilizador aceder ao(s) documento(s) a partir de um endereço de IP da instituição detentora da supramencionada licença.

Ao utilizador é apenas permitido o descarregamento para uso pessoal, pelo que o emprego do(s) título(s) descarregado(s) para outro fim, designadamente comercial, carece de autorização do respetivo autor ou editor da obra.

Na medida em que todas as obras da UC Digitalis se encontram protegidas pelo Código do Direito de Autor e Direitos Conexos e demais legislação aplicável, toda a cópia, parcial ou total, deste documento, nos casos em que é legalmente admitida, deverá conter ou fazer-se acompanhar por este aviso.

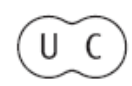


DEBATER

A EUROPA

jul-dez 2014

QUE EUROPA(S)?

CONTEXTOS E DESAFIOS 


\title{
The Atlantic Arc: New Translations for an Old Identity
}

\author{
Tamara Guirao Espineira \\ CAAC Coordinator \\ E-mail: coordinator@atlanticcities.eu
}

\begin{abstract}
For more than thirty years, the Atlantic Arc has been used as a concept to defend the stance of the regions and cities in South Western Europe. Several factors, from geographical features to cooperation agreements have had a strong influence in the evolution of the notion and its uses. Nowadays, with a new EU programming period on its way and transnational initiatives like the Atlantic Strategy being discussed, the time has come to clarify the meaning, the incidence and the implication of the Atlantic Arc as a brand and as a common identity, part of the European citizenship broader concept.
\end{abstract}

Keywords: Atlantic Arc; Atlantic Area; branding; territorial marketing; territorial cooperation

The Atlantic Area is characterised by great differences in development regarding capital regions of each State, and also by relatively important heterogeneity, particularly between the north and south, whilst it is supported by a network of medium-sized cities and constitutes Europe's main maritime façade.

Rooted in identity signs like the Way of Saint James, the Discoveries or the Celtic heritage, the revival of the Atlantic Arc concept as a cultural transformation represents today an opportunity for the territories located in South-West Europe. The concept has endeavoured several interpretations, provided by the cooperation bodies that are installed, the European Institutions and other international actors.

So, after a short overview of symbols, this paper will provide several definitions of the Atlantic Arc, trying to define the geographical scope, the agents and their interactions. These definitions provide the basis to examine the implementation of the Atlantic Arc concept on the ground, exploring how it is declined and perceived as a European identity. Thus, this 
paper would endeavour to classify the strengths and the weaknesses of this strategy in order to identify the initiatives that can influence the future, such as the Atlantic Strategy, the Atlantic City of the Year award or the ATBRAND project.

This research has followed two parallel and complementary methods. The first part of the paper is mainly based on documentary research, and the list of references will show the extension of it. The second part presents the results of the four presentations to-date of the ATBRAND project in different contexts, using different events as simplified focus groups that will guide the construction of a renewed common identity for the Atlantic Arc.

\section{Some Atlantic identity signs}

The first meaning of "Atlantic Area" that comes into mind relates to the relationship between the European Union and the United States of America. The "atlantism" that has given birth to international agreements as NATO or the "Transatlantic Treaty" in discussion, seem the natural arena of the concept. However, even if the Atlantic Arc presents itself as the "gateway of Europe" (the gate to America) the concept this paper intends to discuss is somewhat different. The Atlantic Arc is thus restrained to the cities and regions located in South West Europe, the largest maritime façade of the continent.

Several symbols compose the imagery of the Atlantic Arc. For instance, the Way of Saint James is seen as the inland backbone of the territory, fostering cooperation and exchanges among the Atlantic Regions since its inception and from all the cardinal directions throughout its versions: the French, Way, the English Way, Via de la Plata, etc...

Better known, the Celtic ties between the Atlantic regions still play a major role. Celtic Music has been living a revival since the 80's and Celtic Festivals are spread all over the Atlantic Arc during the summer; as Lorient, Ortigueira, etc. Artists like Carlos Nunez or Alan Stivell represent this music movement that investigates the common roots of music and culture in the area. So the legends of Arthur, the triskell, the pipe and other Celtic images are currently attached to the Atlantic Arc as a background.

Gastronomy is also to be taken into account. Opinions tend to relate the Galician filloas to the French crêpes, passing through the British and Irish pancakes. Far from those folkloric interpretations, the University of Santiago de Compostela created in 2007 the Atlantic Diet Foundation (Sabores Galegos 2011). For them, the Atlantic diet is based, primarily in cooking, grilled, stew and baking rather than frying. They also note several characteristics as: abundance of seasonal food, local, fresh and minimally processed; 
abundance of food from plants: vegetables, fruits, cereals, breads and grains, potatoes, chestnuts, nuts and legumes; plenty of fish consumption, shellfish, molluscs and crustaceans, frozen or canned and a significant consumption of dairy products.

The influence of history cannot be taken out of this major picture. The Atlantic Territories have been the ground of commercial exchanges starting with copper in the Phoenician period, followed by the fishing tradition and more recently the salt industries. Furthermore, we cannot forget that the Atlantic ports have been the gateway to Europe for discovery, from America, Africa or Oceania to the inventions of the industrial revolution. Slavery and the triangular trade, war alliances, common kings and mutual invasions have knitted together these countries for centuries.

\section{From Atlantic Europe to Atlantic Area}

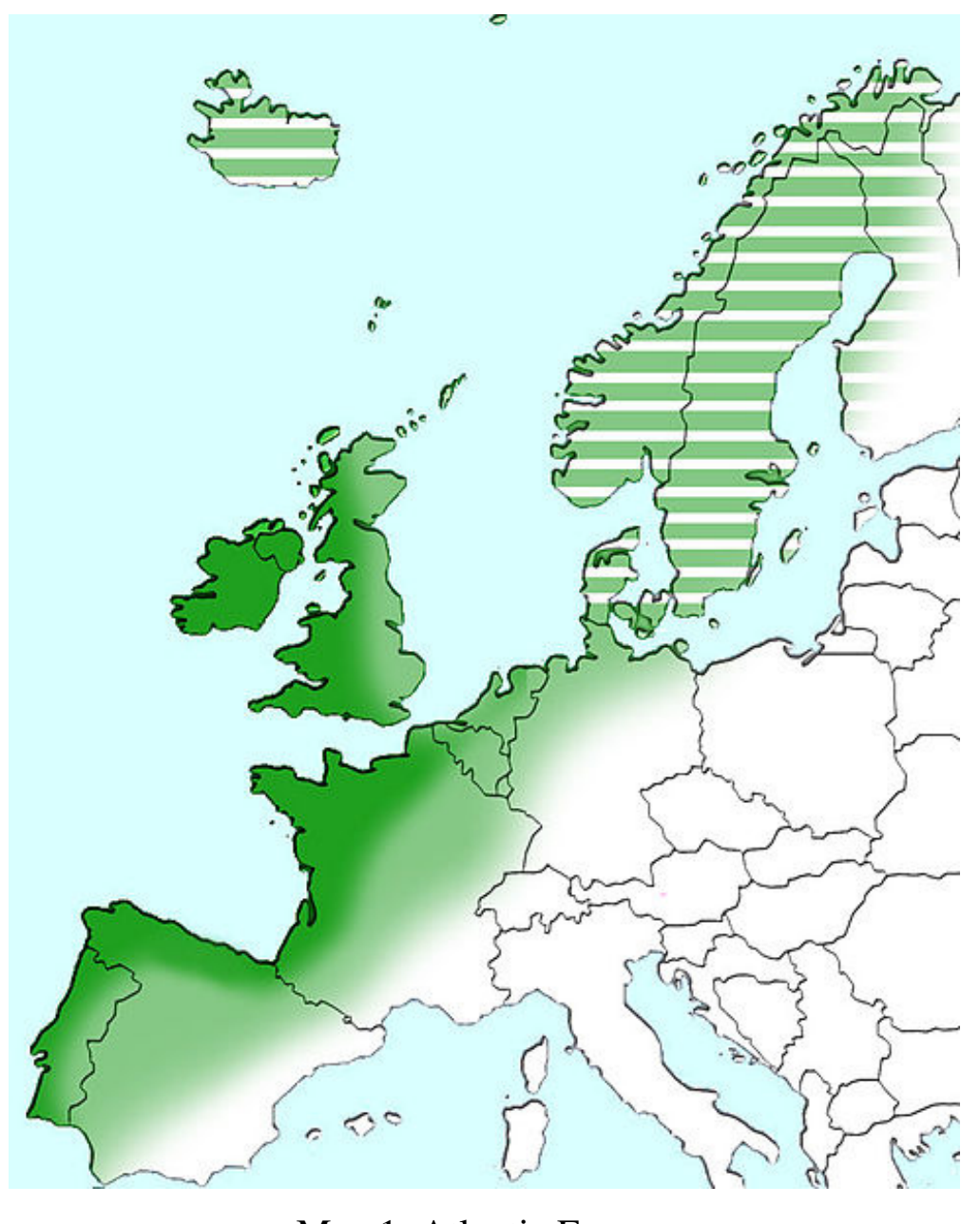

Map 1: Atlantic Europe

As we have already mentioned, there are several definitions of the region encompassing the Atlantic Arc. It is a dynamic concept, from the geopolitical, cultural and 
functional perspectives. The first definition of the European Commission, drafted by Bruce Millan (1994) found the Atlantic Europe in a large area (map 1) which includes all the territories located in West, in a band ranging from Andalusia to Sweden via the Iceland. This concept has fallen into disuse.

For international organisations, such as $\mathrm{FAO}^{1}$ or $\mathrm{OSPAR}^{2}$, the Atlantic area is covered under the denomination "North East Atlantic" (map 2). This area encloses all the waters from the North Pole that surround the West of Europe, going forward to Greenland, being limited at the South by an extension of the Gibraltar strait.

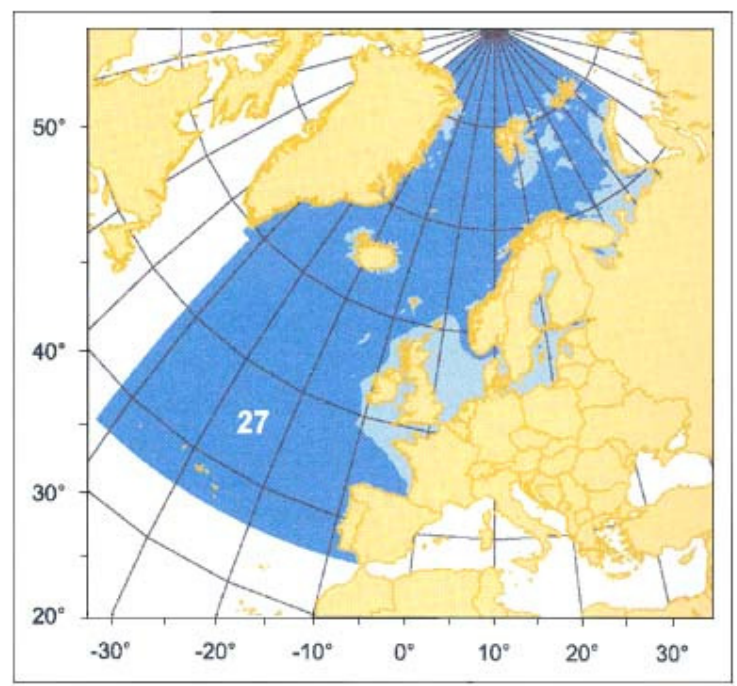

Map 2: Nort East Atlantic

Coming to the European Commission, definitions vary depending upon which Directorate-General is involved. For DG Environment (2009) the Atlantic Region corresponding to the Natura 2000 (map 3) environment encompasses a coastal fringe from the Galician-Portuguese border until Norway.

\footnotetext{
${ }^{1}$ http://www.fao.org/docrep/009/y5852e/Y5852E03.htm

${ }^{2}$ http://www.ospar.org/
} 


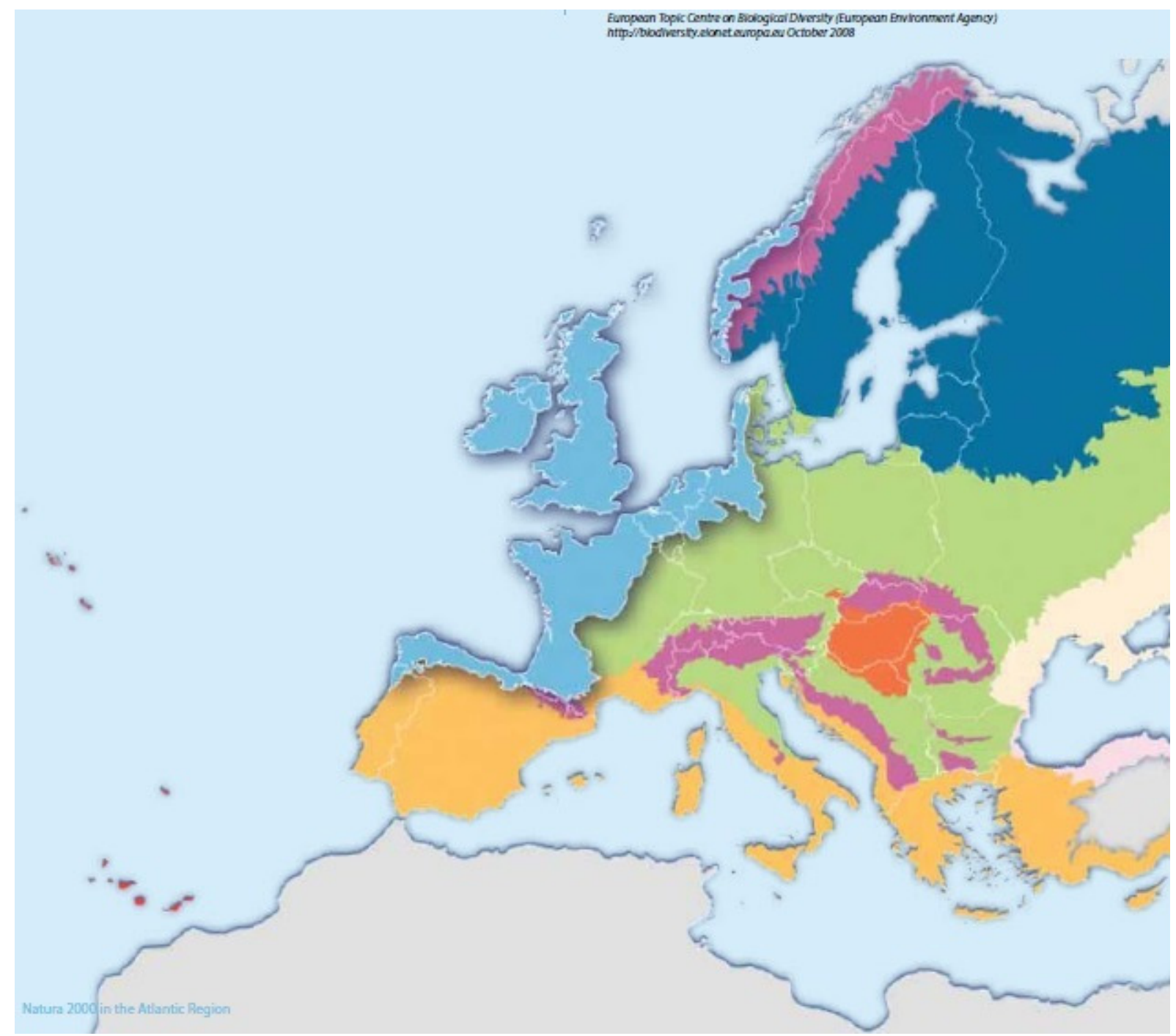

Map 3: Natura 2000 in the Atlantic Region

With the launch of the Integrated Maritime Policy (Blue Book, 2007), the notion of sea basin becomes current in the European Union; thus defining new areas for policy implementation marked off by their marine features. The Atlantic Ocean encompasses two of these EU sea basins ${ }^{3}$, the Celtic Sea and the Bay of Biscay, serving to enhance maritime governance and maritime spatial planning.

However, the idea of "Atlantic Arc" is, at first, a crystallisation of the political will and the development prospective of the South western territories of the European Union. Back in the eighties, the regions of this part of Europe started a joint analysis of the obstacles they faced and the potentialities they shared, so as to start working together for a better recognition of their features at EU level. Thus the nineties saw the creation of a forum known as the

\footnotetext{
${ }^{3}$ http://ec.europa.eu/maritimeaffairs/atlas/seabasins/index_en.htm
} 
Atlantic Arc Commission ${ }^{4}$ and the start of the first projects co-funded by ERDF funds such as ARCANTEL or ATLANTIS (Auffray, 1998).

These projects evolved in an INTERREG II (ESPON, 2013) programme exclusively dedicated to the Atlantic Area. This territorial cooperation programme is currently preparing the contents, objectives and measures of INTERREG V, due to start in 2014. In order to compare with the different definitions mentioned above and so as to insist in the lack of consistency among the Directorates of the European Commission, it is interesting to observe the territorial diversity between INTERREGs (figure 1.) as implemented by DG REGIO. ${ }^{5}$

\section{Atlantic Area Programme}

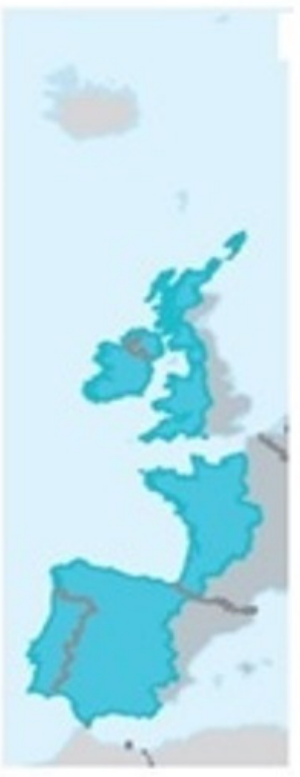

INTERREG ॥

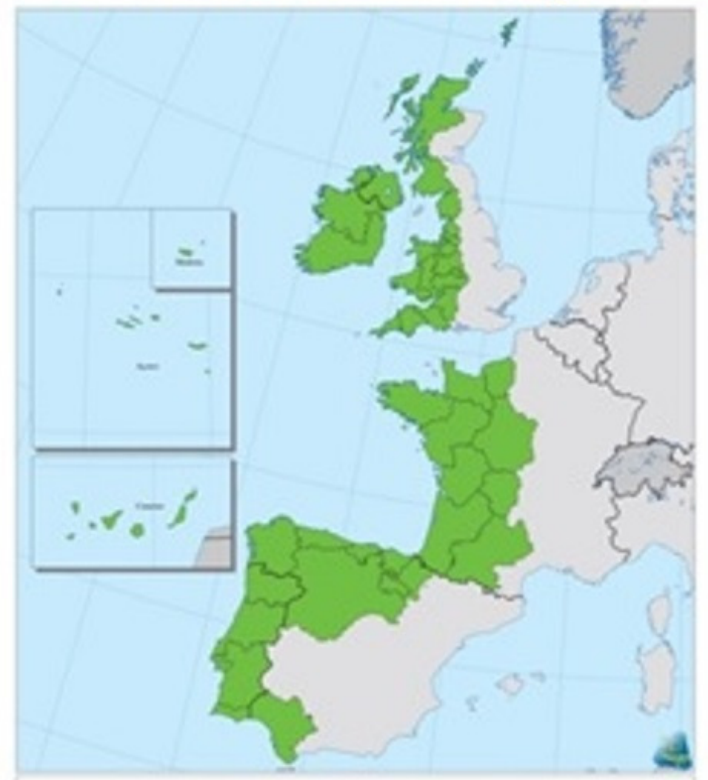

INTERREG III

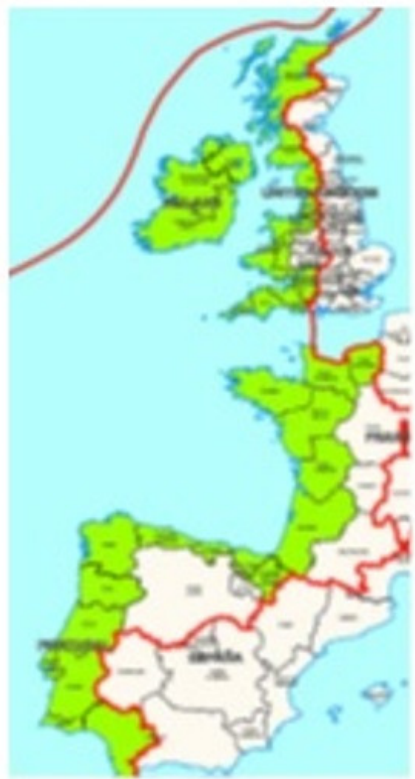

INTERREG IV

Figure 1: Evolution of INTERREG ATLANTIC AREA

\section{Arc or Area? Both and none}

Even if the notion of 'Atlantic area' is created in the 1990s to delimit the areas of European territorial cooperation copying the maps designed by the infant Atlantic Arc Commission, it does not always correspond with the Atlantic Arc as it is understood by political bodies. Following the pattern of development of the territory and the first rider in the

\footnotetext{
${ }^{4}$ http://arcatlantique.org/

${ }^{5} \mathrm{http}$ ://ec.europa.eu/dgs/regional_policy/index_fr.htm
} 
1990's, Atlantis, INTERREG II C (approved in 1998) defines the following Atlantic Area regions:

$\checkmark$ Spain: Andalucía, Asturias, Canarias, Cantabria, Castilla y Léon, Castilla-La Mancha, Extremadura, Galicia, Madrid, Navarra, Pais Vasco and La Rioja.

$\checkmark$ France: Aquitaine, Bretagne, Basse-Normandie, Centre, Haute Normandie, Pays de Loire, Poitou-Charentes and Limousin (associated).

$\checkmark$ Ireland and Portugal: The whole of territories, with Açores and Madeira

$\checkmark$ United Kingdom : Cumbria, Lancashire, Greater Manchester, Cheshire, Merseyside, Shropshire, Staffordshire, West Midlands, Herefordshire, Worcestershire, Warwickshire, Avon, Gloucestershire, Wiltshire, Dorset, Somerset, Cornwall, Devon, Clwyd, Dyfed, Gwynedd, Powys, Gwent, Mid, South et West Glamorgan, Highland and Islands, Dumfries, Galloway, Strathclyde, Northern Ireland, Isle of Man, Gibraltar, Jersey, Guernesey.

Created upon the political consensus on cooperation for these territories, this definition appears as the better assortment to the notion of Atlantic Arc. It reflects the historical and cultural links and seems to respect a clear criterion of geographic continuity. Currently the area is described around common challenges identified by the different bodies that carry out cooperation strategies, as mentioned by the joint policy paper (CAAC 2010) of the Atlantic Arc Commission and the Conference of Atlantic Arc Cities in 2010:

$\checkmark$ The sea: this is the element that unites the Atlantic territories. It offers assets that can all be transformed into development opportunities for the regions. However it is also a fragile area that requires protection. There are therefore great demands to promote a truly sustainable development model.

$\checkmark$ A peripheral area but with an even and close-knit network of Atlantic territories: this structuring of the territory offers the opportunity to develop a dynamic area located far from the centre of the EU, which is based on an interconnected urban network and the link between land and sea (agricultural activity and local economy, link between ports and hinterland, etc.). The accessibility and connectivity of territories is therefore an extremely important factor.

"Sub-areas" with specific issues to be addressed: these are mainly sub-basins such as the English Channel or Irish Sea, land-based or maritime cross-border territories, as well as the outermost regions of Macaronesia. These territories face their own challenges and are developing strong cooperation activities between themselves such as the Arc Manche, Eixo Atlántico or the Working Community of the Pyrenees. These need to be taken into account 
when drawing up an Atlantic strategy

But definitions are still changing.

\section{Who is the Atlantic Arc? A view on stakeholders}

As mentioned before, the Atlantic Arc was born in the eighties from the reflections of the regions of Western Europe (Flatrès, 1993). Gathered in Faro, Portugal, October $13^{\text {th }} 1989$, in the General Assembly of the Conference of Peripheral and Maritime Regions ${ }^{6}$ (CPMR); Brittany and Pays de La Loire, represented by Olivier Guichard, presented a "Resolution on the reinforcement of the cooperation among regions of the Atlantic Arc". This resolution was also supported by the works of French think tanks like the DATAR, the CELIB or Ouest Atlantique.

From this resolution and under the umbrella of the CPMR, 23 regions composed the following year the Atlantic Arc Commission ${ }^{7}$. It covers five states (Ireland, United Kingdom, France, Spain and Portugal) in a territory spreading from Andalucía to Scotland and the presidency of the Atlantic Arc Commission is currently held by the Cantabria Region (Spain). Apart from its responsibilities as facilitator of projects among the regions, it also assumes the task of promoting regional interests to EU bodies and member states.

Three years later, and only in France, the Chambers of Agriculture decided to create a collaboration platform known as Association of the Agricultural Chambers of the Atlantic Arc or $\mathrm{AC} 3 \mathrm{~A}^{8}$. The $\mathrm{AC} 3 \mathrm{~A}$ bestows to EU institutions (Parliament, Commission) and other organizations present in Brussels projects and policy positions about the issues of agriculture in the Atlantic Arc, forecasting trends at medium and long terms.

In 1996, in order to promote watersports in the Atlantic Arc, the same regions set up the International Committee of the Atlantic Watersports Games ${ }^{9}$. Since their creation in Brittany in 1995, the objective of the Atlantic Games is to gather, every year, for a week of competition, delegations of young athletes coming from all the Atlantic regions of Europe: currently more than 14 Atlantic countries or regions take part in the Atlantic Games.

\footnotetext{
${ }^{6} \mathrm{http}: / /$ www.cpmr.org

${ }^{7}$ http://www.arcatlantique.org

${ }^{8}$ http://www.ac3a.fr/AC3A.php

${ }^{9} \mathrm{http}: / / \mathrm{www} . a t$ lanticgames.eu/
} 
The cities have also their say in the cooperation among political entities in the Atlantic Arc. Created in 2000, the Conference of Atlantic Arc Cities ${ }^{10}$ or CAAC gathers today more than 200 local entities and 9 million inhabitants of the Atlantic façade. After nearly fourteen years of experience, the CAAC has asserted its position as an Atlantic Urban Forum, facilitating both the cooperation among its members and with other European and Atlantic Arc actors, creating awareness in the European institutions about issues concerning its members.

The articles of association of the CAAC (CAAC 2, 2010) keep the geographical definition blurred, as its article 3 says that members are among those local entities "located in the European Atlantic Arc and involved in or concerned by its development. “

In 2003 the civil society joined the movement, creating their specific Atlantic roundtable: the Atlantic Transnational Network ${ }^{11}$. This transnational network is composed of Economic and Social Councils of the Atlantic Area regions and / or by analogous regional organisations where these Councils do not exist. This network defines recommendations and formulates projects and interregional cooperation policies. The aim is to promote policies that favour the peripheral regions with common features, so as to improve the integration of the Atlantic regions or to strengthen their competitiveness and their social and territorial cohesion.

\section{Prefiguring the future: the Atlantic Strategy}

In 2008, the mayors of the Atlantic Arc suggested through the Charter of San Sebastian (CAAC 2008), "a more ambitious, more open and more effective cooperation". In 2009 General Assemblies, both of the Atlantic Arc Commission (AAC, 2009) as of the Conference of Atlantic Arc Cities (CAAC 2009) had a clear will to go towards a system of territorial cooperation where the structural funds and sectorial programmes (such as LIFE or the Framework Programme) are grouped in a common effort: the Atlantic macro-region. The presidencies of the two organizations met in September 2009 with the Spanish Presidency of the European Council, proposing a model similar to the Baltic territorial cooperation. This lobbying campaign continues to this day.

\footnotetext{
${ }^{10} \mathrm{http}: / / \mathrm{www}$.atlanticcities.eu

${ }^{11}$ http://rta-atn.eu/en/
} 
The exchanges within the Council of the European Union in 2010 (ibidem) led to a decision that ignores the macro-region approach and creates the Atlantic strategy as Maritime, covering the whole Atlantic façade of Europe (with Açores, Madeira and Canary Islands).

The Commission then began its work and issued a communication in 2011 (European Commission 2011), which was preceded and followed by several positions taken by the Atlantic networks, the European Parliament, the Economic and Social Committee and the Committee of the Regions. In 2012 the Atlantic Forum (European Commission, 2012) was created, consisting of a Steering Committee, a Monitoring Committee, a series of events and a stakeholders' consultation closed in February 2013. From these initiatives sprang an Atlantic Action Plan (European Commission, 2013), sponsored by the Irish presidency and presented in May 2013.

In 2014, a series of events are taking place in the five countries of the Atlantic Arc so as to clarify and define the contents of this Plan. At the same time, Member States are discussing with the Commission how to integrate this Strategy in their Partnership agreements.

However, even if the topics correspond to the ambitions of the Atlantic territories, there is still a significant absence of an urban dimension or a risk of "only coastal" development. Therefore, the territories envisage a broader plan for the Atlantic Arc (CAAC 2013) and had not left down the idea of a complete macro-region, similar to the initiatives currently run in the Baltic or the Danube.

\section{Rethinking the Atlantic Identity:}

Indirectly, the discussions on the Atlantic Strategy led to a questioning around the identity of the Atlantic Arc. Where does it end / start? Is it operational? In order to define and surmount these shortcomings, we have drawn a SWOT analysis (figure2) 


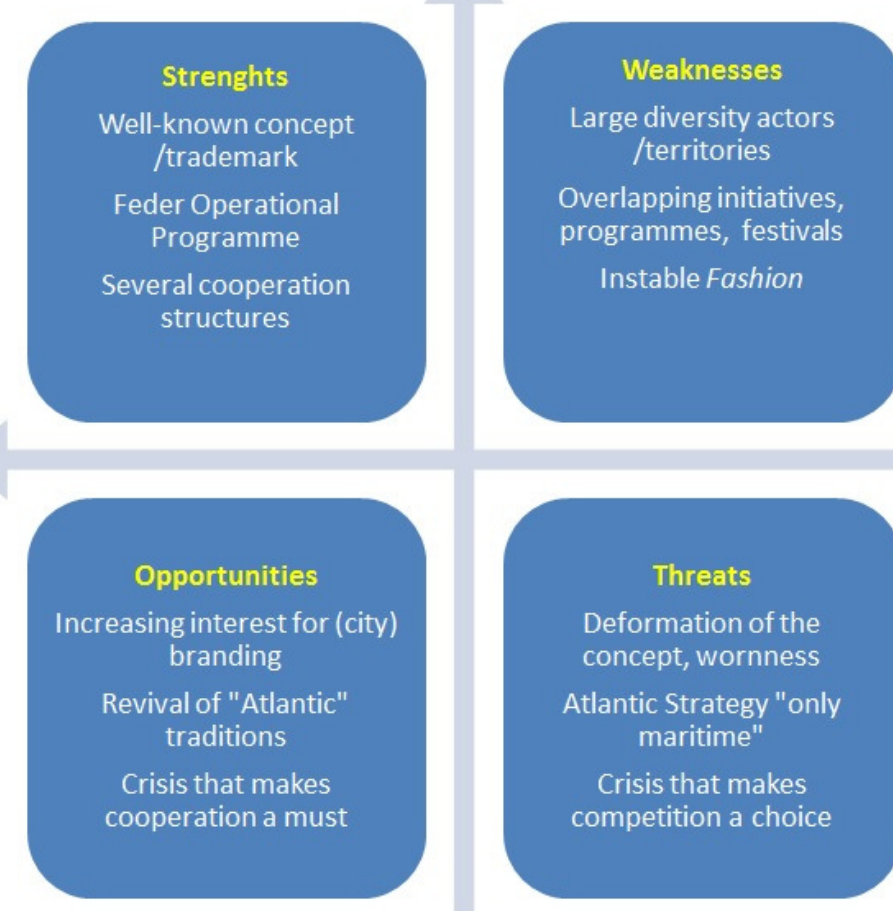

Figure 2: SWOT analysis of the concept Atlantic Arc

In the strengths side, we can affirm that, at European level, it is a well-known concept and /or trademark. EU officials and representatives can easily identify the term and its geographical correspondence. Moreover, the notion of Atlantic Arc has been translated into EU programmes, such as INTERREG Atlantic Area (ERDF funds), the Atlantic Sea Basin and its Maritime Strategy or the Natura 2000 protocol specifically dedicated. In addition, several cooperation structures show a long story of cooperation and the dynamism of the concept is being translated into new ones.

However, as for the weaknesses, this universe of actors leads to a wide diversity of interpretations and actors, and highlights the differences among the different parts of the Atlantic Arc and reducing consistency. At the same time, the absence of regulation for the mark has derived in a variety of overlapping initiatives, such as the multiplication of "Atlantic" festivals, events and even private firms. Observing these twenty years of evolution, the "Atlantic Arc" has also suffered from ups and downs due to instable fashion.

Coming to future opportunities, the increasing interest of European territories on territorial marketing and branding strategies, especially for cities, can be seen as a major boost for a stabilisation of the term. In this sense, the "revival" of the Atlantic traditions and its clear 
links with citizens can favour the adhesion of territorial entities to the label. The economic crisis provides an unexplored ground for cooperation, justifying transnational action.

But threats are yet to be tackled. This continuous production of "Atlantic" items without any clear and compulsory reference may originate the deformation of the concept. The result could be a burst of the Atlantic Arc label due to wornness. The only-maritime focus of the Atlantic Strategy can cause disenchantment of the Atlantic territories that are not located in the coast, leading them to search other non-maritime arguments for their promotion policies. In this sense, the crisis can push them to opt for non-cooperative strategies.

\section{A new start for the Atlantic label}

The push given by the Maritime Strategy to the stance of the Atlantic Arc in the European Union must lean on a practical response from the territories. In this sense, three initiatives can be highlighted: the contest "Atlantic City of the Year", the Working Group "Atlantic Tourism and Culture" and the INTERREG project "ATBRAND".

These last four years have seen an increasing and successful participation of the cities located in the Atlantic area in diverse "City of the year" contests such as European Green City (Vitoria, Nantes), European Capital of Sport (Cardiff, Guimaraes) or European Capital of Culture (Glasgow, Dublin, Lisbon, Santiago de Compostela, Porto, Cork, Liverpool, Guimaraes and San Sebastian.)

In order to respond to the interest shown by Atlantic Cities for this kind of branding, in 2012 the CAAC creates its own label, the "Atlantic City of the year" "to promote the interest and cooperation of the Atlantic cities, bringing them a visibility and recognition via a label of Atlantic urban development". The first edition chose Brest Métropole Ocèane as Atlantic City of the Year $2014^{13}$, for its urban environmental excellence, its innovative economic growth and its Atlantic and Maritime identity. The award was echoed by the French most important media as L'express or Libération. The second edition is currently under way.

At the same time, the member regions of the Atlantic Arc Commission have created a working group on Tourism and Culture in 2012, so as to impulse wider cooperation and to develop concrete actions in the area of Atlantic tourism and culture while responding to the

\footnotetext{
${ }^{12} \mathrm{http} / / /$ atlanticcities.eu/index.php?option=com_content\&view=article\&id=568\%3Aiquien-sera-la-ciudadatlantica-del-ano-en-2015\&catid=40\%3Aciudades-atlanticas\&Itemid=123\&lang=en

$13 \mathrm{http} / / /$ atlanticcities.eu/index.php?option=com_content\&view=article\&id=421:ciudad-atlantica-del-ano-brestmetropole-oceane\&catid=40: ciudades-atlanticas\&Itemid=101\&lang=en
} 
European strategy for Blue Growth, the Atlantic Maritime Strategy, and the Strategy on maritime and coastal tourism. Gathered for the first time in Gijon, Asturias in April 2014 ${ }^{14}$, the goal was to set up the stage for cooperation in the development of an Atlantic label.

Hence, in order to promote the identity and brand image of the Atlantic at local, regional and transnational level, participants during the meeting issued a call to "increase the attractiveness of the Atlantic Area as a tourism destination." Therefore, four major objectives were identified:

$\checkmark$ Enhance the visibility of the Atlantic Arc as a high quality tourism destination in Europe;

$\checkmark$ Reaffirm the tourism and cultural two-fold dimension of the Atlantic destination;

$\checkmark$ Strengthen cooperation between the towns, the regions, as well as the private actors

$\checkmark$ Develop specific common projects through a discussion platform

Moreover, some projects are already being implemented. Following the path opened by INTERREG IIIB $^{15}$ projects such as SDEA or SPAA, the project ATBRAND intends to explore the feasibility of a long-term strategy to co-brand the Atlantic area. The planned activities within the ATBrand project mix research activity and analysis with concrete pilot actions in each partner cities around innovative formulas and solutions of city-brand design and management. All of them are designed to generate knowledge or capacity-building, for the benefit of the partner cities and all practitioners in territorial marketing in the Atlantic area.

Thus, ATBrand will act as a driver for reform in local policy-making, pointing out the way that Atlantic cities will design and manage their branding strategy: integrated approach, multi-level governance, stakeholder involvement and citizen engagement, direct connection of communication and promotion with the strategic objectives for the development of the city, digital based communication channels and tools, etc.

After its kick-off meeting in Dublin, the project has already been presented and discussed in Coimbra, Gijon, and Bordeaux, giving its managers the first bribes of food for thought in the feasibility of a co-branding strategy in the Atlantic Area.

\section{Reality check: primary results of ATBRAND}

As mentioned in the introduction, part of this research has been carried out using the different presentations of ATBRAND as simplified focus groups. The first meeting in Dublin

\footnotetext{
${ }^{14} \mathrm{http} / / \mathrm{www}$.arcatlantique.org/index.php?act=1,4,2,52

${ }^{15}$ http://www.interreg-atlantique.org/eng/
} 
counted on the participation of the cities partnering the project: Dublin, La Rochelle, Liverpool, Cardiff, San Sebastian, Faro and CAAC as facilitator. After a thorough discussion on how the project was to be implemented, the cities concerned presented their own branding strategies. From these presentations and the debate that followed, three initial conclusions can be taken out:

$\checkmark$ The approach to city branding is very different depending on the country, the size of the city, and the local development strategy

$\checkmark$ Identity and branding are not always analogous. While identity is seen a fact (static) branding is perceived as a strategy to obtain particular goals (dynamic)

$\checkmark$ The possibilities of individual and joint Atlantic identity and branding are yet to be explored, the concept being approached very differently by the partners.

The second presentation was held during the "Debater a Europa" International Conference in Coimbra. It is worth to note that it was included with the more international talks on the relationship with the U.S. in the Kennedy era and an update on the Ukraine situation seen by the diaspora. Also noteworthy, even if the public was composed by students and experts on international relations, the question of "what do you know about the Atlantic Arc" remained unanswered. This experience served as a pre-test for the ATBRAND project concerning citizens' engagement. It shows that the Atlantic Arc concept has still to be widely disseminated and translated into common language before it could be suitable to be transmitted to citizens.

The third presentation took place during the meeting of the Atlantic Working Group on Culture and Tourism. Participants were representatives of regions and cities of the Atlantic Area working on tourism and international promotion. In general, some of the ideas that were raised concerning the Atlantic Identity were:

$\checkmark$ Enhance the sustainability (green) dimension of the Atlantic Arc.

$\checkmark$ Ensure the links between the "Atlantic area" brand with quality tourism, well-preserved cultural heritage, nature and protected coasts, gastronomy and medium-sized cities.

$\checkmark$ Avoid competition between regional tourism strategies: a transnational strategy

$\checkmark$ Benchmark the Atlantic area internationally as a differentiated destination that offers specific products: experience-based tourism, surfing, water sports, protected designations of origin (gastronomy), sea and mountains, history and heritage.

$\checkmark$ Foster ownership of Atlantic territorial attractions by its inhabitants 
Concerning ATBRAND project, discussions focused on the demand from the Atlantic Area territories to build a common identity, the need to avoid a severe and unique link to the Celtic background, and the difficulties posed by the transnational approach.

Last but not least, the project was presented end of April to the Executive Bureau of CAAC in Bordeaux. The first exchanges were focused in the technicalities related to the implementation. As not all the members of CAAC are partners, the project risks to be seen as an external and (maybe) expensive activity. Secondly, it was proposed to earmark the project in the overall strategy of the Atlantic Cities, namely the Urban Strategy for the Atlantic Arc. As 2014 is a pivotal year for the new European policy, CAAC must raise awareness of the importance of the Atlantic cities to European institutions. Supported by the network, cities need to be creative and innovative in order to achieve tangible results. In this sense, ATBRAND is seen as an opportunity to expand the network to other cities, as well as to make more visible the works of CAAC. In addition, a strong link with the contest "Atlantic City of the Year" has to be defined. As it happened in Dublin, the cities present in Bordeaux also see the advantages of this initiative to enhance individual branding strategies, but the difficulties of finding common ground and a transnational approach have been highlighted.

\section{Some conclusions}

The Atlantic Arc is a concept under evolution. Even if its political meaning seems to be clear for local, regional, national and European authorities, this cannot be yet affirmed. At the same time, the notion of Atlantic Arc means nothing or little (the Celtic link) to citizens and civil society.

The construction of the Atlantic Arc identity has been mainly based on lobby strategies so as to recover a central part to be played in European policies, and, as it is shown by the Maritime Atlantic Strategy, this approach has proven successful. However, at the time of viral information and the predominance of social media, the Atlantic Arc has to find new translations so as to be easily grasped by the average citizen.

Initiatives like the "Atlantic City of the Year" award or the ATBRAND project, together with the works of the working group on Atlantic Tourism and Culture, seem to head in the right direction. Nevertheless, the transnational dimension remains a difficult task.

Is there an identity for the Atlantic Arc? It should come with the next tide. 


\section{References}

AAC, Atlantic Arc Commission, Minutes of the General Assembly of the Atlantic Arc Commission in Santander 2009 (internal document)

Auffray, Danièle, L'Arc Atlantique. Réalité historique et renaissance des années 1990. Son avenir pour le XXIe siècle In: Norois. N¹80, 1998. L'Atlantique et les géographes. pp. 609615

CAAC, Conference of Atlantic Arc Cities, Atlantic Charter of San Sebastián for sustainable urban development. Green, attractive and solidarity-based cities. 2008, seen at http://www.atlanticcities.eu

CAAC, Conference of Atlantic Arc Cities, Minutes of the General Assembly of the Conference of the Atlantic Arc Cities in Caen in 2009 (internal document)

CAAC, Conference of Atlantic Arc Cities, Atlantic Arc Commission, Proposed guidelines for an integrated strategy for the Atlantic Arc, 2010 seen at http://www.atlanticcities.eu

CAAC, Conference of Atlantic Arc Cities, Articles of Association, September 2010, seen at http://www.atlanticcities.eu

CAAC, Conference of Atlantic Arc Cities, Contribution of the Atlantic Cities to the call for suggestions on Key investment and research priorities - Atlantic Forum 2013, seen at http://www.atlanticcities.eu

Council of the European Union Conclusions on integrated maritime policy 3022nd GENERAL AFFAIRS Council meeting Luxembourg, 14 June 2010

ESPON, ESaTDOR, European Seas and Territorial Development, Opportunities and Risks. , ANNEX 9 to the Scientific Report Governance Case Studies: Atlantic Ocean. Applied Research 2013/1/5. Version 16/1/2013 
European Commission, Blue Book: Communication from the Commission to the European Parliament, the Council, the European Economic and Social Committee and the Committee of the Regions - An Integrated Maritime Policy for the European Union \{COM(2007) 574 final) European Commission, Communication from the Commission to the European Parliament, the council, the European Economic and Social Committee and the Committee of the Regions Developing a Maritime Strategy for the Atlantic Ocean Area Brussels, 21.11.2011 $\operatorname{COM}(2011) 782$ final

European Commission, Vision Paper for the Atlantic Forum 2012, internal working document seen at http://ec.europa.eu/maritimeaffairs/policy/sea_basins/atlantic_ocean/atlanticforum

European Commission, Communication from the Commission to the European Parliament, the council, the European Economic and Social Committee and the Committee of the Regions: Action Plan for a Maritime Strategy in the Atlantic area, Delivering smart, sustainable and inclusive growth Brussels, 13.5.2013 COM(2013) 279 final

Flatrès, Pierre, Europe Atlantique et Arc Atlantique, Norois Poitiers t. 40 n¹57 P. 35-43 1993

Millan, Bruce, Coopération pour l'aménagement du territoire européen - Europe 2000 Plus, Bruxelles, Commission des Communautés européennes, 1994, 247 p. (ISBN 92-826-9100-4)

Sundseth, Kerstin, Ecosystems LTD, Brussels, Natura 2000 in the Atlantic Region European Commission Environment Directorate General European Communities 2009

\section{Websites consulted}

http://www.fao.org/docrep/009/y5852e/Y5852E03.htm

http://www.ospar.org/

http://ec.europa.eu/maritimeaffairs/atlas/seabasins/index_en.htm

http://arcatlantique.org/

http://ec.europa.eu/dgs/regional_policy/index_fr.htm

http://blog.saboresgalegos.com/la-dieta-atlantica

http://www.cpmr.org

http://www.arcatlantique.org 
http://www.ac3a.fr/AC3A.php

http://www.atlanticgames.eu/

http://www.atlanticcities.eu

http://rta-atn.eu/en/ 